\title{
Irfani
}

ISSN 1907-0969 E ISSN 2442-8272

Volume 14 Nomor 2 Desember 2018

Halaman 84-96

http://journal.iaingorontalo.ac.id/index.php/ir

\section{Olah Tubuh Dalam Praktek Seni Budaya Pada Siswa Kelas 3 Sekolah Dasar}

\author{
Nurnaningsih Hasan \\ IAIN Sultan Amai Gorontalo
}

\begin{abstract}
Abstrak
Olah tubuh dalam praktek seni budaya pada siswa kelas 3 sekolah dasar. Tujuan dari penelitian ini untuk mengungkapkan bahwa olah tubuh penting dalam praktek seni budaya khususnya seni pertunjukan drama dan tari pada siswa sekolah dasar. Olah tubuh sebagai langkah awal sebelum memulai praktek bisa dikatakan pemanasan. Hal ini dilakukan untuk mempersiapkan tubuh melakukan gerakan-gerakan yang memerlukan tenaga dan energi yang kuat.

Rangkaian gerakan olah tubuh ini dapat menjadi dasar atau referensi bagi siswa untuk dalam praktek drama dan tari. Dalam praktek drama melatih gesture atau gerak tubuh berakting agar tidak kaku, sedangkan dalam praktek tari kegunaan olah tubuh untuk mendapatkan teknik tari yang benar, bentuk gerak tari akan terlihat jelas.
\end{abstract}

Kata Kunci : Olah Tubuh, Seni Budaya, Sekolah Dasar

\section{Pendahuluan}

Salah satu bentuk inovasi yang dikembangkan pemerintah guna meningkatkan mutu pendidikan adalah melakukan perubahan di bidang kurikulum. Kurikulum adalah seperangkat rencana dan pengaturan mengenai tujuan, isi dan bahan pelajaran, serta cara yang digunakan sebagai pedoman penyelenggaraan kegiatan pembelajaran, untuk mencapai tujuan pendidikan tertentu. Di dalamnya mencakup perencanaan, penerapan dan evaluasi.

Setelah mengalami beberapa perubahan dari awal dibentunya kurikulum, dari tahun 1947 sampai tahun 2013. Akhirnya ditetapkan kurikulum yang sampai sekarang dipakai yaitu kurikulum 2013, Digunakan untuk Sekolah Dasar, Sekolah Menengah Pertama Dan Sekolah Menengah Atas. Kurikulum ini dikenal dengan Kurikulum 2013 (K13), yang memberikan otonomi kepada sekolah untuk menyelenggarakan pendidikan yang puncak tugasnya itu akan diemban oleh masing masing guru. Disini seorang guru benar-benar diarahkan menjadi profesional dan kreatif.

Penerapan kurikulum di sekolah perlu direncanakan terlebih dahulu. Perencanaan merupakan langkah awal membangun kurikulum. Tim penyusun kurikulum membuat keputusan dan mengambil tindakan, untuk menghasilkan perencanaan yang akan digunakan oleh guru dan peserta didik, serta diusahakan dapat dijalankan ke dalam tindakan operasional untuk kemudian di evaluasi.

Diketahui bahwa ada beberapa mata pelajaran di sekolah yang menyangkut teori maupun praktek. Untuk itu diperlukan rencana pelaksanaan pembelajaran, yang sesuai dengan materi yang berbentuk teori maupun praktek. Pelajaran seni budaya di sekolah dasar sampai menengah atas membutuhkan waktu praktek 
lebih banyak dibandingkan teori, khusunya untuk praktek drama dan tari, dengan asumsi bahwa seni drama tari adalah aktivitas berbasis gerak untuk perkembangan psikomotor siswa.

Tari pada kenyataannya merupakan penampilan gerak tubuh, sedangkan drama membutuhkan gesture gerak untuk berakting. Gerak sebagai unsur pokok tari tercipta dari tubuh yang menjadi bahasa non verbal untuk dapat mengungkapkan makna gerak yang dilakukan. Hal ini sesuai dengan pendapat Smith, seharusnya cukup jelas bahwa gerak adalah bahasa komunikasi yang luas, dan variasi dari berbagai kombinasi unsur-unsurnya terdiri beribu-ribu "kata" gerak, juga dalam konteks tari gerak sebaiknya dimengerti sebagai makna dalam kedudukan dengan lainnya. Seringkali frase aksi yang menggambarkan makna satu kata atau sebaliknya satu gerak dapat memberikan seluruh isi paragraf ${ }^{1}$.

Ditinjau dari pendapat di atas, gerak dalam tari dan drama sangat penting dan seharusnya gerak yang dihasilkan penari dan aktor dapat mengungkapkan makna tarian maupun bahasa tubuh dalam drama. Untuk itu perlu adanya olah tubuh yang dapat membantu melenturkan tubuh, serta sebagai perbendaharaaan gerak untuk merangkai gerak tari. Olah tubuh yaitu mengolah atau menyiapkan tubuh melakukan aktifitas yang dilakukan untuk berbagai bidang seperti bidang olahraga khususnya atlet dan senam, serta bidang seni. Dalam bidang seni, olah tubuh diterapkan untuk seni teater dan seni tari. Bagian yang diolah meliputi gerak kaki, badan, tangan, leher dan kepala, yang bertujuan mengencangkan otot, menyempurnakan bentuk badan, membangun kekuatan badan, mengembangkan kelenturan fisik, membakar lemak dan menstabilkan nafas atau sirkulasi nafas serta denyut nadi.

Penerapan metode ini bertujuan mengenalkan dari awal siswa sekolah dasar tentang olah tubuh sehingga dapat merangsang kemampuan merangkai gerak tari dan bergerak luwes berakting, karena olah tubuh sebaiknya diterapkan sejak dini untuk dapat mengembangkan kemampuan dasar. Manfaatnya dapat ditindaklanjuti oleh guru-guru sekolah dasar ,yaitu menjadi prosedur atau langkah memperbaiki prosedur pembelajaran seni budaya. Penerapan latihan olah tubuh secara rutin untuk mendukung peningkatan hasil belajar seni budaya khususnya praktek seni tari dan drama, serta menjadi acuan dan evaluasi untuk lebih meningkatkan proses pembelajaran. Manfaat lainnya dapat memotivasi dan menumbuhkan hasrat siswa untuk belajar dan berkreasi seni tari dan drama.

Metode yang digunakan dalam penulisan ini adalah metode kualitatif yaitu sebuah penelitian yang mengola data secara kualitatif, dengan bentuk penyajian analisis deskriptif. Sudjana berpendapat bahwa analisis deskriptif bertujuan untuk mendeskripsikan atau menjelaskan peristiwa dan kejadian yang ada sekarang ${ }^{2}$, yang akan dideskripsikan adalah kemampuan siswa kelas IV Sekolah Dasar melakukan olah tubuh.

\footnotetext{
${ }^{1}$ Smith, Jacqueline. 1985. Komposisi Tari Sebuah Petunjuk Praktis Bagi Guru. Tejemahan Ben Suharto. Yogyakarta, Ikalasti.

${ }^{2}$ Sudjana Nana. 1989, Penilaian Hasil Proses Belajar Mengajar. Bandung. PT Remaja

Rosdakarya.
} 


\section{Pembahasan}

Metode olah tubuh ini dilakukan untuk merangsang kemampuan berkreasi tari dan drama pada siswa kelas 3 Sekolah Dasar, dilaksanakan delapan kali pertemuan. Melalui dua tahap olah tubuh dengan alokasi waktu 40 menit setiap kali pertemuan. Olah tubuh yang akan diterapkan yaitu olah tubuh dasar yang sesuai dengan kemampuan siswa kelas 3 sekolah dasar atau bagi pemula . Tubuh yang di olah meliputi kepala, badan, tangan dan kaki, dengan berbagai macam gerak, untuk lebih jelasnya ada pada deskripsi gerak olah tubuh.

Gerak olah tubuh yang diterapkan terdiri dari 15 gerak yang dibagi dalam 2 kali pertemuan. Pertemuan pertama 11 gerak olah tubuh dengan tingkatan dari yang mudah sampai yang sulit, 4 gerakan diterapkan pada pertemuan kedua. 4 gerak terakhir yang diterapkan tingkat kesulitannya lebih dari tahap sebelumnya. Setelah siswa melakukan olah tubuh, mereka termotivasi membuat sesuatu dari hasil olah tubuh, untuk itu peneliti menugaskan mereka merangkai gerak dari hasil olah tubuh dan tidak dibatasi apabila mereka mengembangkan gerak atau membuat variasi gerak sendiri.

\subsection{Tahap Olah Tubuh}

\subsubsection{Olah Tubuh Tahap 1}

Peneliti menentukan gerak olah tubuh tahap I sebanyak 11 gerak, dengan tingkat kesulitan bertahap dari yang rendah sampai yang menengah. Berikut adalah deskripsi gerak yang dilengkapi gambar olah tubuh yang diterapkan kepada siswa :

1. Badan berdiri tegak, sikap pandangan mata lurus ke depan, tangan bertolak pinggang. Lakukan gerak menolehkan kepala tunggal ke kanan dan kiri secara bergantian. ( Hitungan $3 \times 8$ ).

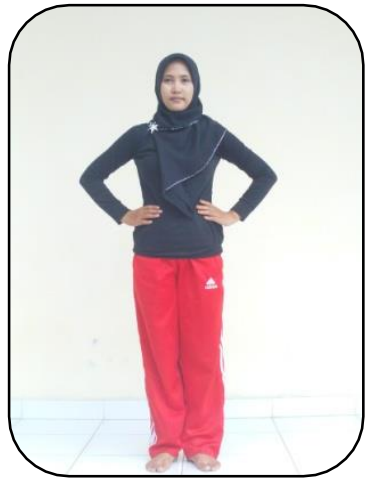

Gambar 1. Bertolak pinggang

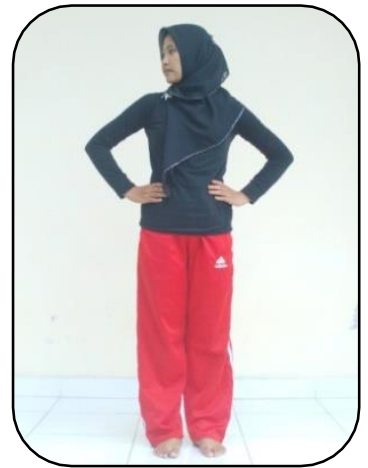

Gambar 2. Menoleh ke kanan

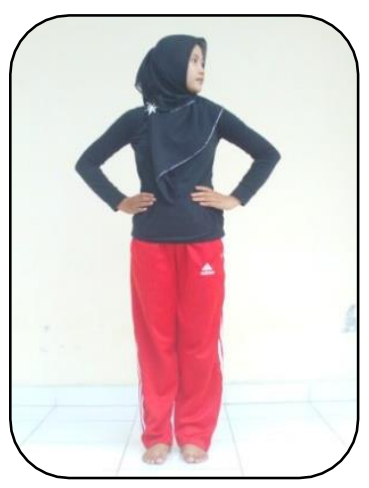

Gambar 3. Menoleh ke kiri

2. Badan berdiri tegak, sikap pandangan mata lurus ke depan, tangan bertolak pinggang. Lakukan gerak mematahkan kepala tunggal ke kanan dan kiri secara bergantian. ( Hitungan 3 X 8 ). 


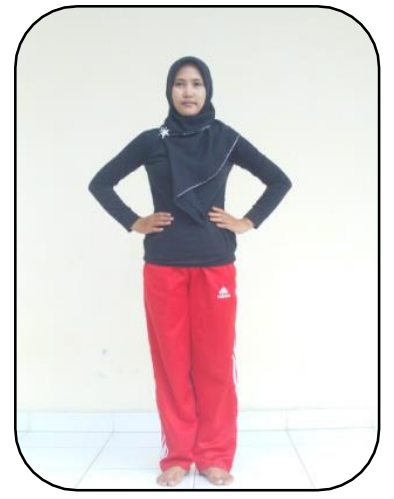

Gambar 4.

Bertolak Pinggang

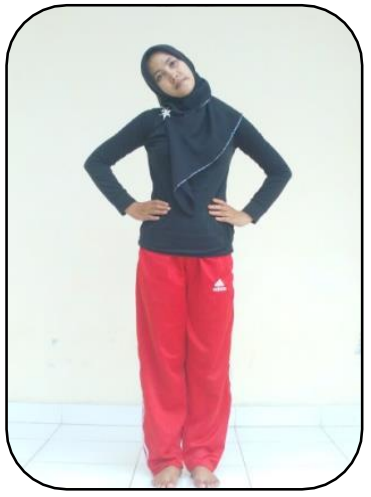

Gambar 5

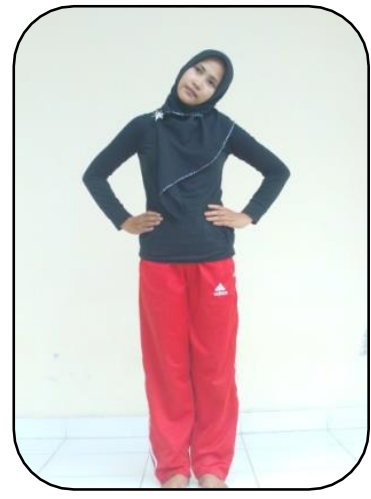

Gambar 6.

Mematahkan ke kanan Mematahkan ke kiri

3. Badan berdiri tegak, sikap pandangan mata lurus ke depan, tangan bertolak pinggang. Lakukan gerak anggukan kepala tunggal ke bawah dan ke atas secara bergantian. ( Hitungan $3 \times 8$ ).

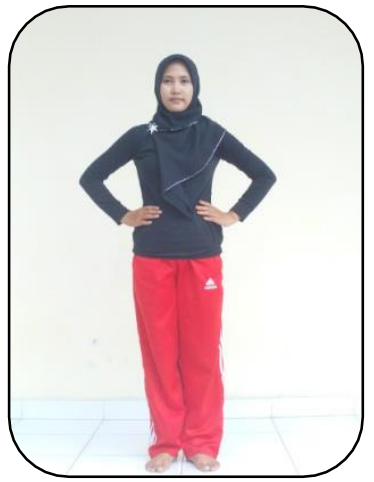

Gambar 7.

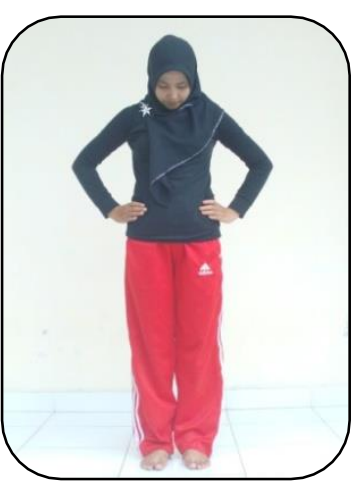

Gambar 8.

Angguk ke bawah

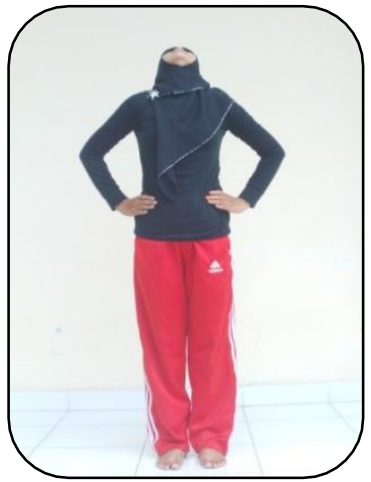

Gambar 9.

Kepala menegadah

4. Badan berdiri tegak, sikap pandangan mata lurus ke depan, tangan bertolak pinggang. Lakukan gerak memutar kepala ke arah kanan dan ke kiri membentuk 360 derajat secara bergantian. ( Hitungan 3 x 8 ).

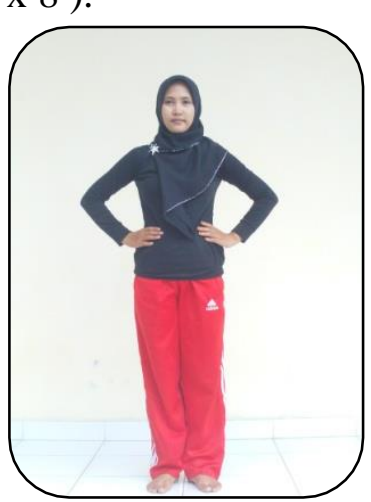

Gambar 10.

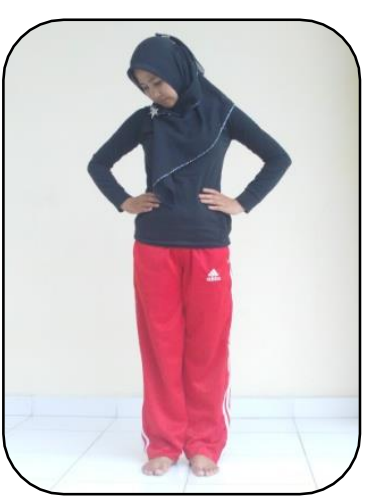

Gambar 11.

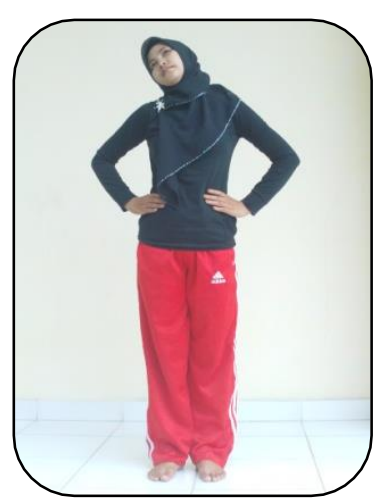

Gambar 12 . 
Bertolak pinggang Putar ke kanan $\quad$ Putar ke atas

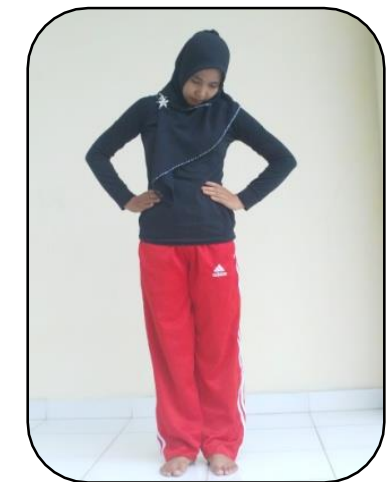

Gambar 13.

Putar ke kiri

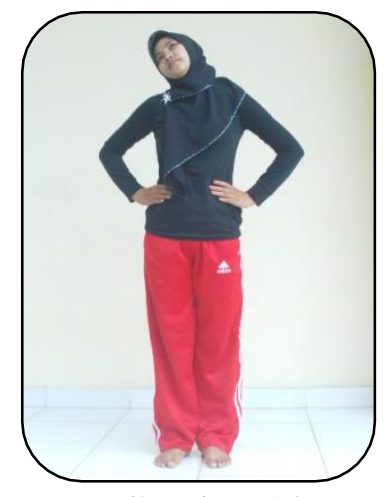

Gambar 14.

Putar ke atas

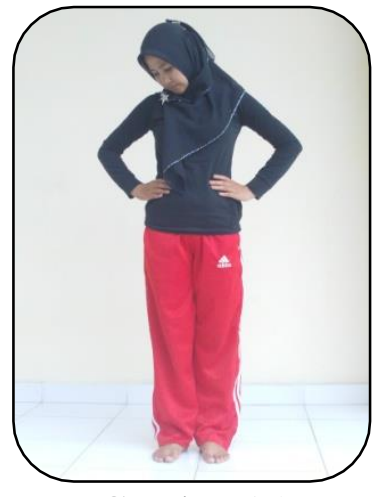

Gambar 15.

Putar ke depan

5. Badan berdiri tegak, sikap pandangan mata lurus ke depan, tangan lurus disamping paha. Lakukan gerak mengangkat dan menurunkan bahu( Hitungan 3 x 8 ).

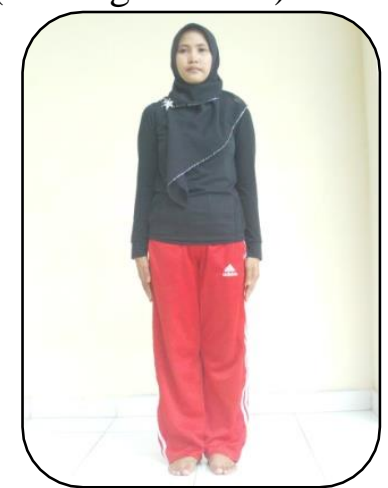

Gambar 16.

Berdiri tegak

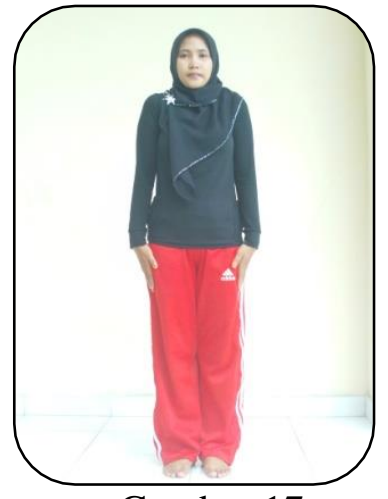

Gambar 17.

Mengangkat bahu ke atas

6. Badan berdiri tegak, sikap pandangan mata lurus ke depan, tangan lurus disamping paha. Lakukan gerak memutar sendi bahu ke belakang dan ke depan. ( Hitungan 3 x 8 ).

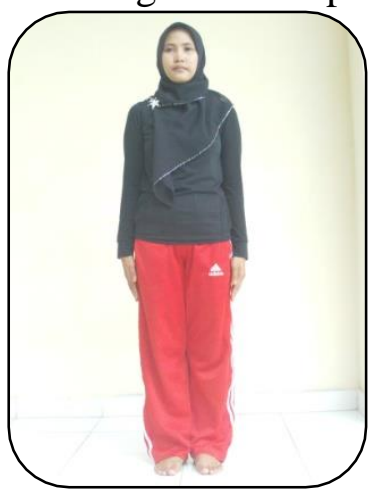

Gambar 18. Berdiri tegak

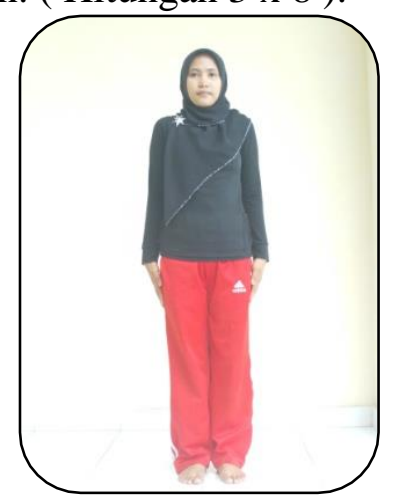

Gambar 19.

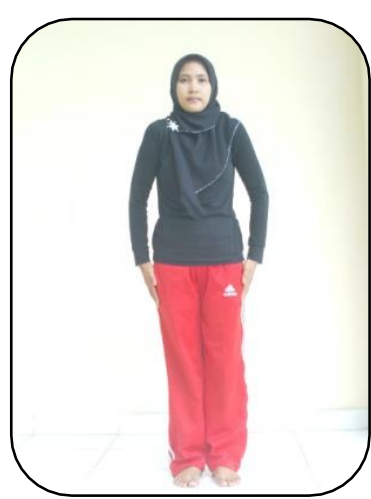

Gambar 20.

Putar bahu ke belakang Putar bahu ke depan 
7. Badan berdiri tegak, sikap pandangan mata lurus ke depan, tangan lurus disamping paha. Lakukan gerak memutar tangan ke depan secara bergantian tangan kanan dan kiri. ( Hitungan 3 x 8 ).

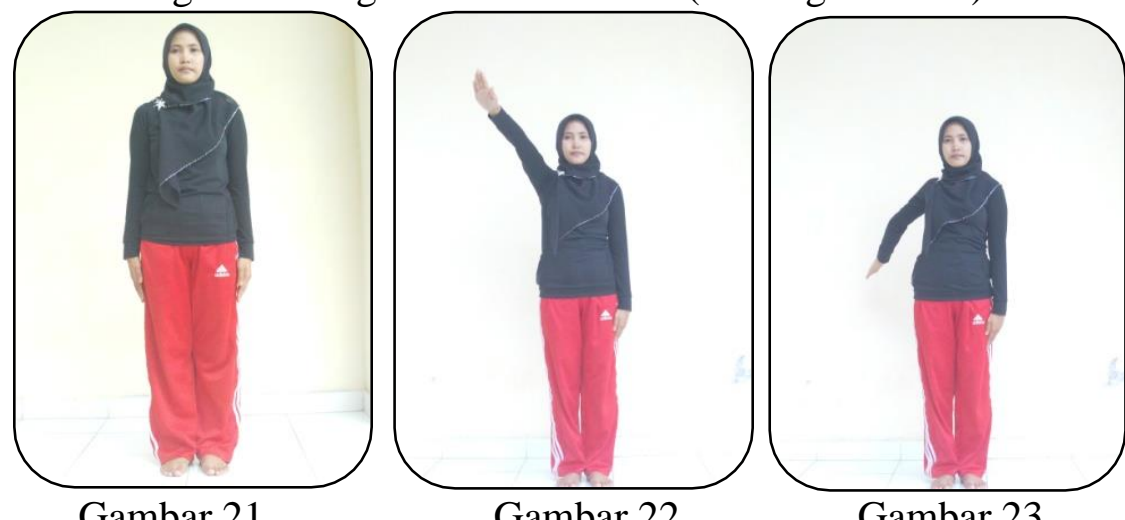

Berdiri tegak Tangan kanan putar ke depan Putar ke belakang

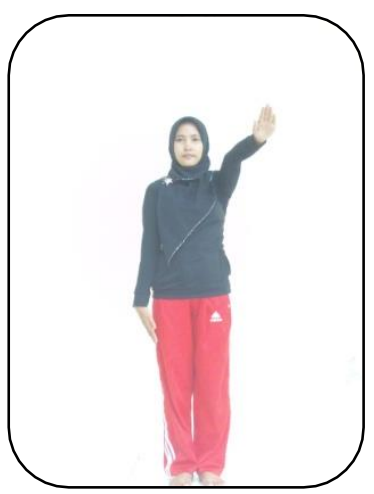

Gambar 24.

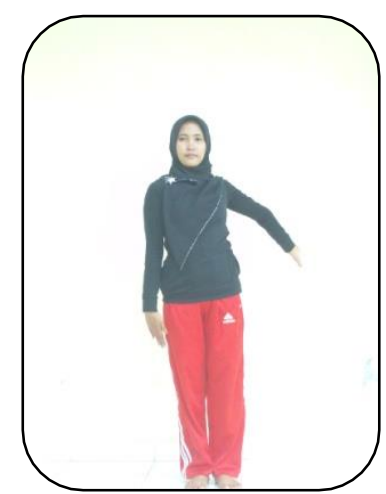

Gambar 25.

Tangan kiri putar ke depan Tangan kiri putar ke belakang

8. Badan berdiri tegak, sikap pandangan mata lurus ke depan, tangan melebar ke samping sejajar bahu. Lakukan gerak memutar tangan ke depan dan kebelakang secara bergantian. ( Hitungan 3 x 8 ).

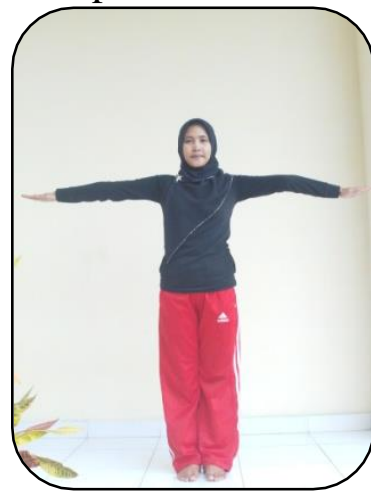

Gambar 26.

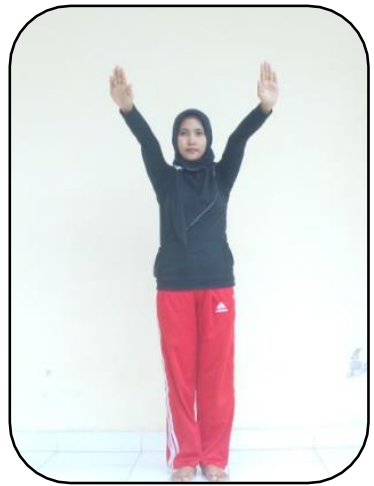

Gambar 27.

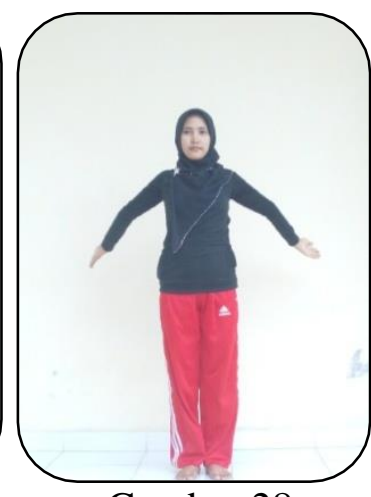

Gambar 28.

Tangan lebar ke samping Putar tangan ke depan Putar ke belakang 
9. Badan berdiri tegak, sikap pandangan mata lurus ke depan, kedua tangan angkat ke atas gerakan jari meregam. Gerakan menjulurkan tangan, posisi kaki jinjit seolah- olah meraih benda yang berada paling jauh. ( Hitungan $3 \times 8$ ).

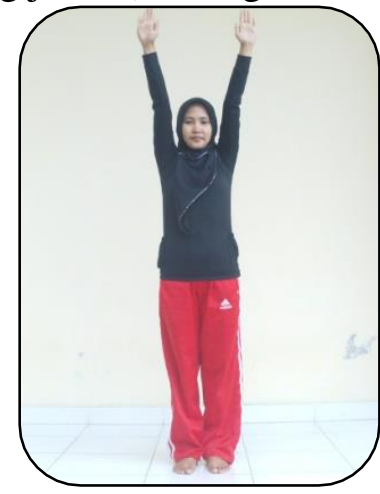

Gambar 29.

Tangan lurus ke atas

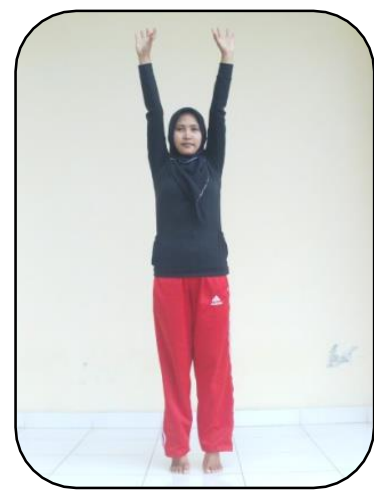

Gambar 30.

Kaki jinjit

10.Badan berdiri tegak, sikap pandangan mata lurus ke depan. Gerakan kaki kombinasi, kaki kanan ditekuk ke depan sampai menyentuh perut, lipat didepan paha, dilipat ke belakang menyantuh pantat, gerakan dilakukan bergantian kaki kanan dan kiri.( Hitungan 3 x 8 ).

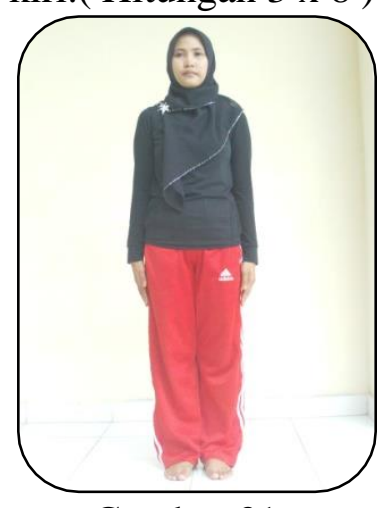

Gambar 31.

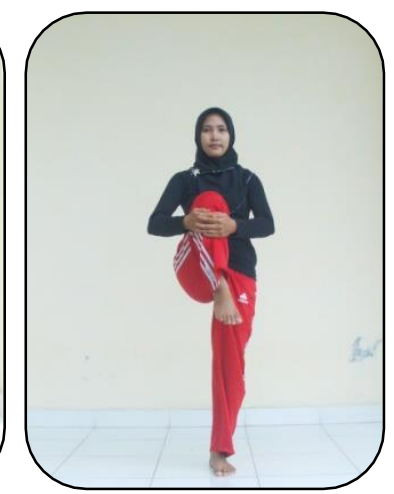

Gambar 32.

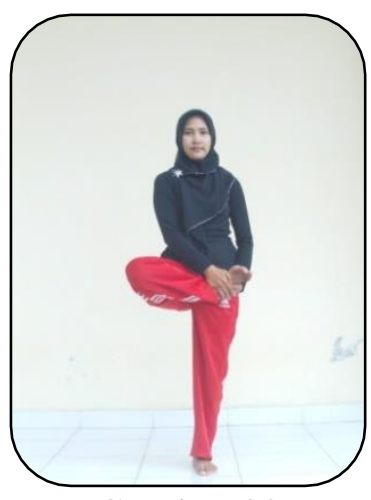

Gambar 33.

Kaki kanan tekuk di perut Lipat depan paha
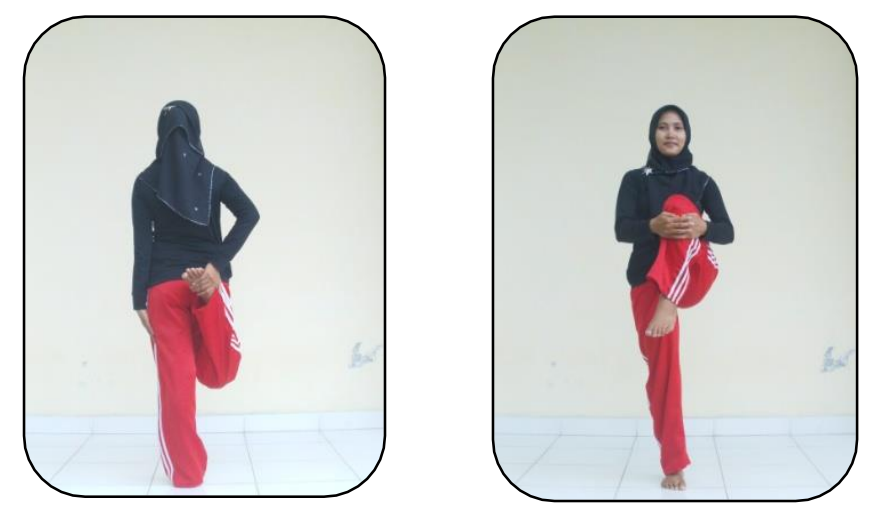
Gambar 34.

Kaki kanan lipat ke belakang

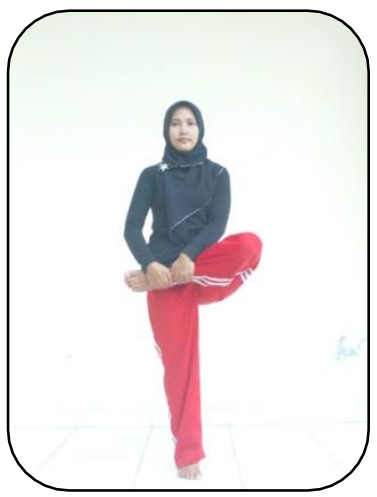

Gambar 36.

Lipat depan paha
Gambar 35.

Kaki kiri ditekuk sampai perut

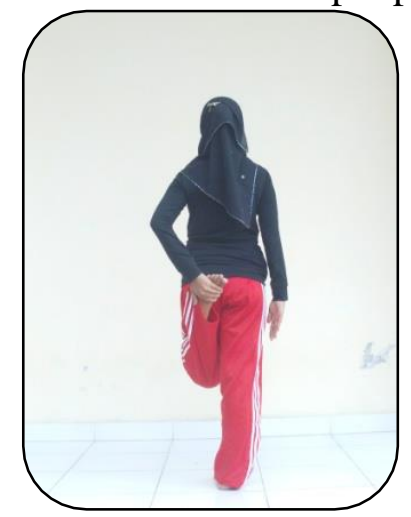

Gambar 37.

Lipat ke belakang

11.Badan berdiri tegak, sikap pandangan mata lurus ke depan, tangan bertolak pinggang. Gerakan berjalan maju, lakukan gerak jalan tunggal dan ganda bergantian kaki kanan dan kiri.

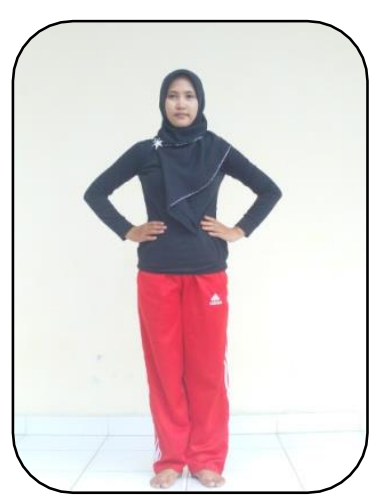

Gambar 38.

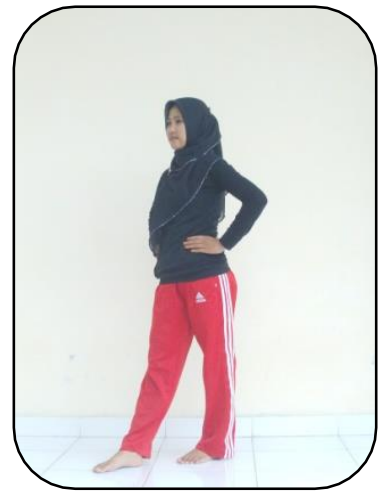

Gambar 39.

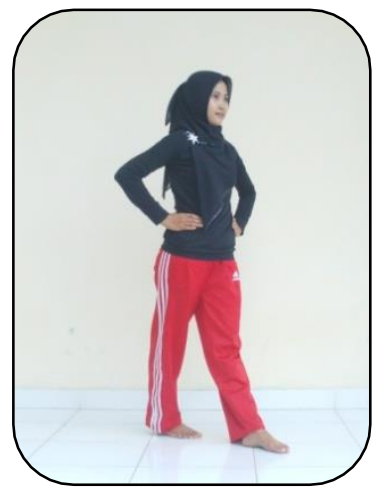

Gambar 40.

Bertolak pinggang Kaki kanan melangkah Kaki kiri melangkah

Pertemuan pertama model mempraktekan olah tubuh tahap I secara berurut, dari gerakan 1 sampai 11. Penerapan olah tubuh ini menggunakan metode demonstrasi, yaitu model mempraktekan satu persatu gerakan, kemudian siswa secara bersamaan mengikuti gerak yang dilakukan model. Peneliti mengamati proses yang siswa lakukan, apabila siswa tidak mengikuti gerak yang dilakukan model, maka peneliti mengarahkan model untuk mengulang kembali gerakan tersebut. Dalam waktu 40 menit, model bersama siswa mengulang 3 kali 11 gerak olah tubuh secara utuh.

\subsubsection{Olah Tubuh Tahap 2}

Olah tubuh tahap 2 peneliti menentukan empat gerak dengan tingkat kesulitan lebih dari gerak pada tahap I. Berikut deskripsi gerak yang dilengkapi gambar olah tubuh tahap kedua : 
1. Badan berdiri tegak, sikap pandangan mata lurus ke depan, kedua tangan lurus kedepan sejajar bahu, jari - jari vertikal. Gerakan mempertemukan ujung jari telunjuk sampai jari kelingking dengan ibu jari, gerakan dilakukan bergiliran. Hitungan ( 3 x 8 ).

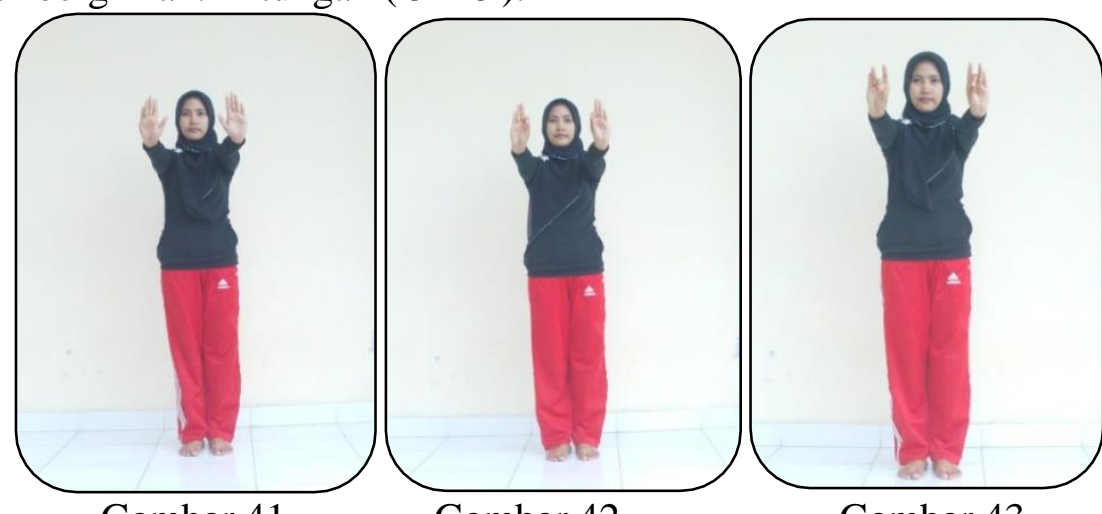

Gambar 41.

Gambar 42.

Gambar 43.

Tangan lurus kedepan Mempertemukan jari Mempertemukan jari

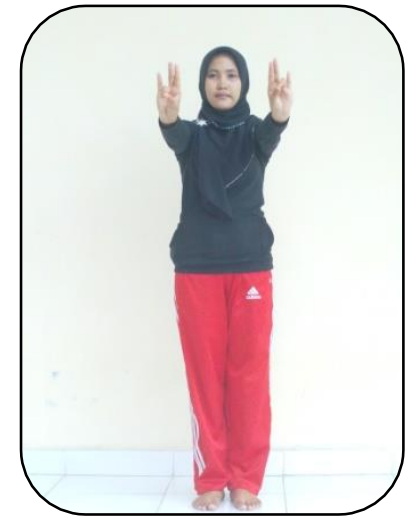

Gambar 44.

Mempertemukan jari

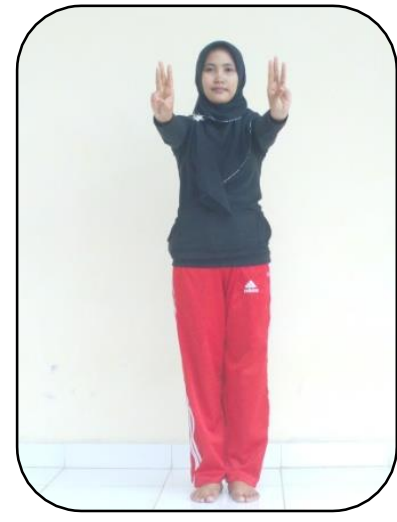

Gambar 45.

Mempertemukan jari

2. Kedua kaki dibuka 90 derajat, badan merendah tangan kiri menyentuh ujung jari kiri, tangan kanan lurus ke atas sehingga terbentuk garis diagonal dari tangan kanan ke tangan kiri, pandangan mengikuti arah jari yang di pegang. Gerakan dilakukan bergantian antara kaki kiri dan kanan.(Hitungan 3 x 8). 


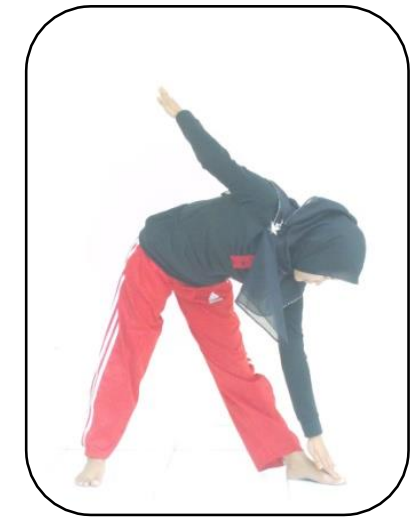

Gambar 46.

Menyentuh kaki kiri

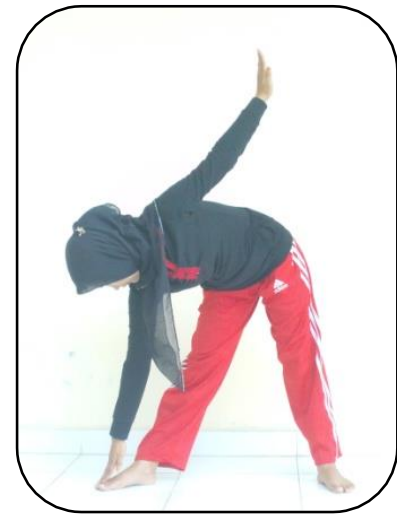

Gambar 47.

Menyentuh kaki kanan

3. Badan tegak merendah menumpu pada kedua kaki yang terbuka 90 derajat, tangan bertolak pinggang, lakukan gerakan memutar badan ke samping kanan dan kiri. Gerakan dilakukan secara bergantian kanan dan kiri. (Hitungan $3 \times 8$ ).

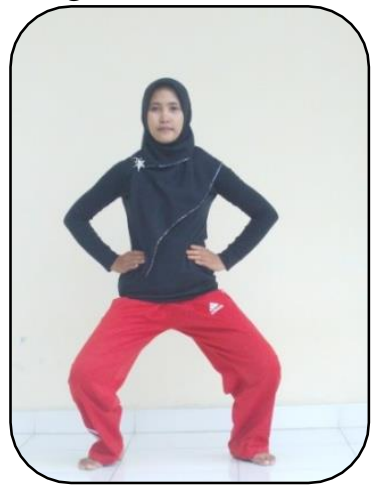

Gambar 48.

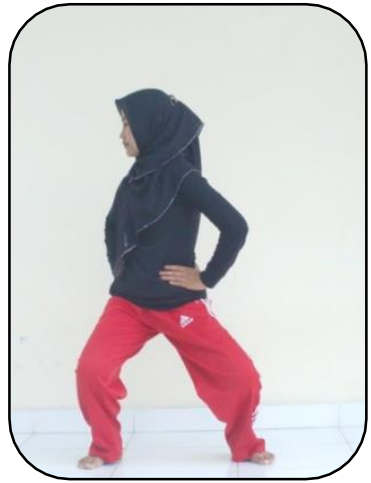

Gambar 49.

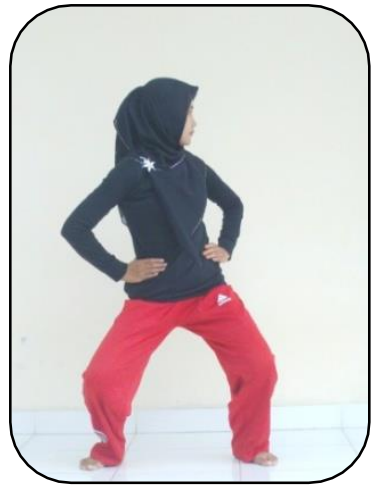

Gambar 50.

Badan merendah Badan putar ke kanan Putar ke kiri

4. Badan tegak merendah menumpu pada kedua kaki yang terbuka 180 derajat, kedua tangan lurus kesamping sejajar bahu jari - jari vertikal, lakukan gerakan tangan kiri diayun menyentuh lengan tangan kanan kemudian dibalikkan keposisi semula. Gerakan dilakukan secara bergantian tangan kanan dan kiri, pandangan mengikuti arah tangan yang disentuh. ( Hitungan $3 \times 8$ ).

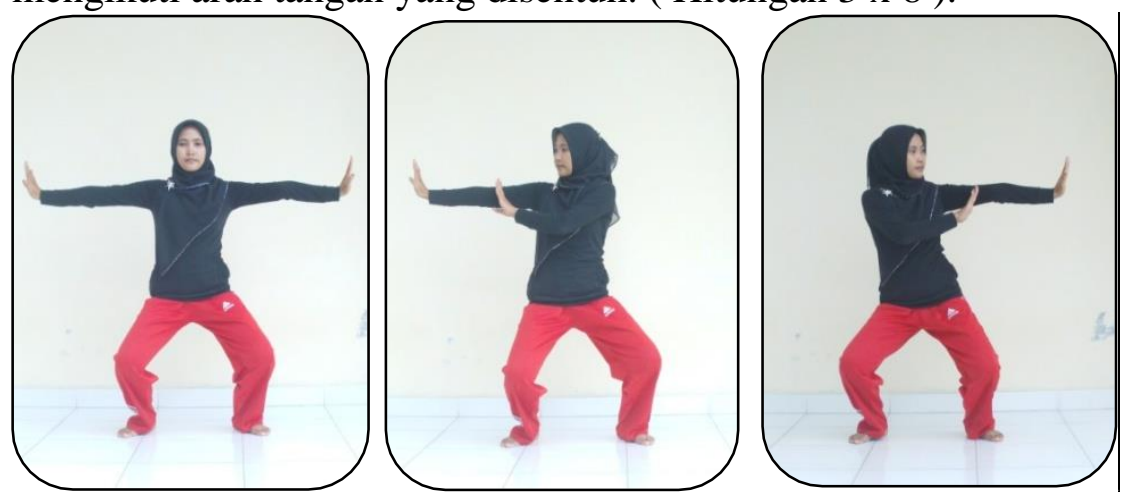


Gambar 51. Gambar 52. Gambar 53.

Badan merendah Tangan di ayun ke kanan Tangan diayun ke kiri

Awal pertemuan kedua, model dan siswa bersama-sama mempraktekkan olah tubuh tahap 1, kemudian melanjutkan olah tubuh tahap 2. Penerapan olah tubuh ini menggunakan metode demonstrasi, yaitu model mempraktekkan satu persatu gerakan, kemudian siswa secara bersamaan mengikuti gerak yang dilakukan model. Peneliti mengamati proses yang siswa lakukan, apabila siswa tidak mengikuti gerak yang dilakukan model, maka peneliti mengarahkan model untuk mengulang kembali gerakan tersebut. 4 gerak olah tubuh tahap 2 ini dilakukan dalam waktu 40 menit, 3 kali pengulangan gerak secara utuh.

Penerapan olah tubuh ini sangat bermanfaat menambah perbendaharaan gerak siswa, selain tujuan utama olah tubuh yaitu mengencangkan otot, merubah bentuk badan, membangun kekuatan badan, mengembangkan kelenturan fisik, membakar lemak dan menstabilkan nafas atau sirkulasi nafas serta denyut nadi, sehingga siswa tidak akan kesulitan dalam merangkai gerak dan saat menari tidak kaku bergerak.

\section{Kesimpulan}

Penerapan metode olah tubuh pada mata pelajaran seni budaya dan keterampilan pada siswa kelas 3 sekolah dasar ini dapat disimpulkan hal - hal sebagai berikut :

1. Olah tubuh dapat mengasah kreativitas siswa kelas VII, semua itu terbukti dengan siswa mampu merangkai gerak, memberi unsur dinamika, level gerak, pola lantai serta memberi unsur musik.

2. Tidak terbiasanya melakukan olah tubuh sebelum praktek menari dan drama membuat siswa akan merasa kesulitan melakukan gerak yang dilakukan model.

3. Setelah siswa menguasai olah tubuh yang diberikan oleh model dalam 2 kali pertemuan, tubuh mereka sedikit lentur dari yang sebelumnya.

4. Olah tubuh tidak saja digunakan untuk pemanasan sebelum melakukan aktivitas, tatapi dapat menjadi media menciptakan gerak tari.

5. Dengan media olah tubuh dapat merangsang kemampuan siswa merangkai gerak tari sederhana, karena olah tubuh menambah perbendaharaan gerak selain gerak tari tradisi yang siswa kuasai.

6. Siswa dapat belajar mengkomposisi tari dengan memberi unsur dinamika, level gerak, pola lantai dan memberi unsur musik pada hasil rangkaian gerak yang mereka buat.

\section{Daftar Pustaka}

Abduracman, Rosid. 1979. Pendidikan Kesenian Seni Tari. Jakarta, PT.Rais Utama.

Arikunto, Suharsini. 1988. Prosedur Penelitian. Jakarta, Akademik Presindo. 
Daulima, Farha. 2006. Tarian Daerah Tradisional Dan Klasik Gorontalo. Gorontalo, Forum suara perempuan LSM Mbi’i Bungale.

Dennison, Paul E. 2002. Brain Gym. Jakarta, PT Gramedia.

Fathoni, Abdurrahmat. 2005. Metodologi Penelitian Dan Teknik Penyusunan Skripsi. Jakarta, PT Rineka Cipta.

Hadi, Sumandiyo. 2005. Sosiologi Tari. Yogyakarta, Pustaka.

2007. Kajian Tari Teks dan Konteks. Yogyakarta, Pustaka Book Publisher.

Hamalik, Oemar. 2007. Dasar-dasar Pengembangan Kurikulum. Bandung, PT Remaja Rosdakarya.

Humphrey, doris. 1983. Seni Menata Tari terjemahan Sal Murgiyanto.Jakarta, Dewan Kesenian Jakarta.

Margono, S. 2009, Metodologi Penelitian Pendidikan. Jakarta, PT Rineke Cipta.

Munandar,Utami S.C.1992, Mengembangkan Bakat dan Kretivitas Anak Sekolah. Jakarta, PT Gramedia Widiasarana.

Muryanto. 2008. Mengenal Seni Tari Indonesia. Semarang, PT Bengawan Ilmu.

Rahmat, Abdul. 2007. Excellent Learning. Bandung, MQS Publishing.

RM , Yoyok. 2007. Pendidikan Seni Budaya Kelas VII SLTP. Jakarta, Yudhistira.

Sedyawati, Edi, dkk. 1986. Pengetahuan Elementer Tari dan Beberapa Masalah Tari. Jakarta, Direktorat Kesenian Jakarta.

Setiawati, Rahmida. 2008. Seni Tari Untuk SMK. Jakarta, Direktorat Jenderal Manajemen Pendidikan Dasar dan Menengah.

Smith, Jacqueline. 1985. Komposisi Tari Sebuah Petunjuk Praktis Bagi Guru. Tejemahan Ben Suharto. Yogyakarta, Ikalasti.

Sudjana Nana. 1989, Penilaian Hasil Proses Belajar Mengajar. Bandung. PT Remaja Rosdakarya.

Sunarto, H. 2008. Perkembangan Peserta Didik. Jakarta, PT Rineke Cipta.

Sukmadinata Syaodih Nana. 1997, Pengembangan Kurikulum. Bandung. PT Remaja Rosdakarya. 
Widaryanto, F.X. 2009. Koreografi Bahan Ajar. Bandung, Jurusan tari STSI Bandung.

Royce Peterson Anya. 2007. Antropologi tari Terjemahan F.X. Widaryanto. Bandung, Sunan Ambu pres STSI Bandung. 